\title{
PENGARUH METODE AUDIOVISUAL DENGAN METODE DEMONSTRASI TERHADAP PENGUASAAN TEKNIK DOLLYO CHAGI
}

\author{
Taupik Rochman $^{1}$, Vickry Maulana Yusuf $^{2}$, Agung Brata Wijaya $^{3}$ \\ ${ }^{1}$ Pendidikan Jasmani Kesehatan dan Rekreasi, Fakultas Keguruan dan Ilmu Pendidikan \\ Universitas Suryakancana,Indonesia \\ taupikrochman@unsur.ac.id ${ }^{1}$,Vickryyusuf337@gmail.com², agungbw@gmail.com³
}

\begin{tabular}{l}
\multicolumn{1}{c}{ Info Artikel } \\
\hline Sejarah Artikel: \\
Diterima Maret 2020 \\
Disetujui April 2020 \\
Dipublikasikan Juni 2020
\end{tabular}

\begin{abstract}
Abstrak
Pentingnya penguasaan teknik dollyo chagi bagi atlet tae kwon do menjadi latar belakang penelitian ini, mengingat teknik tersebut merupakan salah satu teknik dasar yang memiliki tingkat kesulitan yang tidak terlalu tinggi namun sangat efektif untuk menghasilkan angka dalam pertandingan. Proses latihan merupakan salahsatu kunci utamanya apalagi didukung dengan penggunaan model latihan yang tepat, karena itu penulis tertarik untuk membandingkan secara ilmiah antara metode audiovisual dengan metode demonstrasi. Metode penelitian yang digunakan adalah eksperimen dengan populasi seluruh siswa kelas VII yang mengikuti ekstrakurikuler Taekwondo di Madrasah Tsanawiyah I'anatut Thalibin yang berjenis kelamin laki-laki sebanyak 20 orang, dan pengambilan sampelnya menggunakan teknik total sampling. Hasil analisis data yang diperoleh menunjukan bahwa latihan teknik dollyo chagi dengan menggunakan metode audiovisual ( $\mathrm{t}_{\text {hitung }} 49.45>\mathrm{t}_{\text {tabel }}$ 2.26) maupun metode demonstrasi ( $\mathrm{t}_{\text {hitung }} 36.14>\mathrm{t}_{\text {tabel }} 2.26$ ) sama-sama memberikan pengaruh yang signifikan terhadap peningkatan kemampuan dollyo chagi. Dihitung dengan uji signifikan perbedaan dua rata-rata satu pihak diperoleh perbedaan pengaruh yang signifikan dari kedua bentuk latihan tersebut dan dapat disimpulkan bahwa latihan yang menggunakan metode audiovisual ( $t_{\text {hitung }}$ 49.45) memberikan pengaruh yang lebih signifikan dibandingkan dengan latihan yang menggunakan metode demonstrasi ( $\mathrm{t}_{\text {hitung }} 36.14$ ) terhadap penguasaan dollyo chagi.
\end{abstract}

Kata kunci

Metode Audiovisual,

Metode Demonstrasi, Teknik

Dollyo Chagi

Abstrack

Keyword:

Audiovisual

Method,Demonstration

Method,Dollyo Chagi's

technique

The importance of mastering the technique dollyo chagi for athletes Tae kwon do this background research, considering that this technique is one of the basic techniques that has a high degree of difficulty and is very effective for generating numbers in the game. The process of training is one of the main keys especially supported by the use of an appropriate exercise model, therefore the authors are interested in comparing scientifically between audiovisual methods with demonstration methods. The research method used is experiment with a population of all eighth grade students joining the Taekwondo extracurricular at the Tsanawiyah 
I'anatut Thalibin Madrasah with 20 men, and sampling using a total sampling technique. The results of data analysis obtained show that the practice of dollyo chagi technique using audiovisual method ( $t_{\text {test }}$ 49.45> $\left.t_{\text {table }} 2.26\right)$ and the demonstration method ( $t_{\text {test }} 36.14>t_{\text {table }} 2.26$ ) both have a significant effect on increasing the ability of dollyo chagi. Calculated by a significant test of the difference in the two average one party obtained a significant difference in the effect of the two forms of exercise and it can be concluded that exercises using the audiovisual method ( $t_{\text {test }} 49.45$ ) have a more significant effect compared to exercises using the demonstration method ( $\left.t_{\text {test }} 36.14\right)$ to the mastery of dollyo chagi.

(C) 2020 Universitas Suryakancana e-ISSN : 2721-7175 (online) p-ISSN : 2089-2341 (cetak)

\section{PENDAHULUAN}

Ketika kita membahas tentang prestasi seorang atlet, maka akan banyak sekali hal yang harus kita bahas, banyak sekali aspek yang harus kita kupas dan analisa sehingga kita dapat mengetahui dengan jelas dan pasti apa yang menyebabkan prestasi atlet tersebut naik atau turun.

Selain aspek internal aspek ekternal pun sangat berpengaruh sekali, salah satu aspek ekternal tersebut adalah peran seorang pelatih. Seperti yang dikemukakan oleh Harsono (2004:6) bahwa : "Pelatih adalah bak seorang arsitek bangunan". Karena apabila perencanaan gambar rumah yang akan dibangunnya tidak sesuai dengan hukumhukum arsitektur, maka rumah itu akan mudah roboh, meskipun kualitas bahanbahan bangunannya tinggi. Demikian juga sebaliknya walaupun perencanaan atau gambarnya sesuai dengan hukum-hukum arsitektur, tetapi bahan-bahan bangunannya berkualitas rendah, rumah yang dibangunnya pun akan mudah roboh. Karena itu, kalau mau mencetak prestasi yang bagus bagi atlet-atletnya, seorang pelatih dalam merencanakan program latihan harus mengacu kepada hukumhukum, prinsip-prinsip, dan metodologi pelatihan yang benar. Karena tanpa itu semua niscaya apa yang diharapkan dari seorang pelatih terhadap atletnya akan sulit tercapai, karena menurut (Suherly Dina Saputra \& Syamsul taufik, 2019) training merupakan proses yang amat kompleks yang melibatkan banyak sekali variabel, salah satu saja variabel tersebut bermasalah maka akan sangat berpengaruh terhadap hasil prestasi.

Selain perencanaan yang bagus seorang pelatih juga harus mau mengadopsi disiplin-disiplin ilmu yang erat hubungannya dengan meningkatkan prestasi, antara lain faal olahraga, anatomi, ilmu gizi, hukum-hukum 


\section{Taupik Rochman ${ }^{1}$}

Pengaruh Metode Audiovisual Dengan Metode Demonstrasi Terhadap Penguasaan Teknik Dollyo Chagi

biomekanika, psikologi olahraga, dan lain-lain. karena dengan ilmu pengetahuan yang memadai, tentunya seorang pelatih akan jauh lebih sukses dalam menciftakan atlet-atlet yang sesuai dengan harapannya. Selain itu juga untuk menjadi seorang pelatih yang baik dan sukses tidak cukup hanya dengan mengandalkan pengalaman semata, hal ini sesuai dengan pendapat Harsono (2004:13) bahwa : "Pelatih yang masih mengawetkan teori dan sistem melatih yang sudah usang tak akan efektif dalam melakukan tugasnya sebagai pelatih". Karena itu seorang pelatih harus terus aktif untuk selalu menambah ilmu yang dimilikinya dan kreatif dalam memilih dan menggunakan metode pelatihan yang sesuai untuk atletnya, atau bahkan kalau perlu membuat metode latihan baru sehingga proses latihan yang dilakukan selalu lebih baik dan berkualitas dari sebelumnya sehingga dapat mencapai target yang telah ditetapkan sebelumnya.

Tanpa penguasaan ilmu-ilmu pengetahuan yang mendukung, kecil kemungkinan seorang menurut (Kurniawan, 2018) pelatih dapat berhasil dengan baik dalam pekerjaannya. Apalagi jika seorang pelatih memiliki pengetahuan sekedarnya yang hanya menyentuh permukaan atau fenomena persoalan saja dan bukan inti persoalan yang sebenarnya, tidak akan dapat memberikan hasil-hasil yang memuaskan dan prestasi-prestasi yang optimal, apalagi prestasi maksimal.
Pengetahuan setengah-setengah saja tentang sesuatu masalah justru biasanya akan menghasilkan informasi-informasi yang setengah-setengah pula. Malah dalam banyak hal sering menghasilkan informasi-informasi yang salah, keliru, atau bertolak belakang dengan maksud yang dituju.

Banyak orang setuju dan sepakat bahwa seorang pelatih harus memiliki ilmu pengetahuan yang memadai, tetapi melatih bukan sekedar itu, penguasaan ilmu pengetahuan saja bukan satu-satunya syarat untuk bisa menjadi seorang pelatih yang efektif dan baik. Kita tidak bisa hanya mengandalkan diri dengan membaca dan menggeluti buku-buku tentang coaching dan kemudian mengharapkan bisa menjadi pelatih yang baik. Tetapi menurut (Rivan Syukur \& Kastrena, 2019) seorang pelatih juga harus memiliki kemampuan untuk menyampaikan informasi dengan baik sehingga atletnya dapat menangkap setiap maksud dan materi yang diungkapkan atau diberikan pelatih kepadanya dengan baik dan cepat.

Begitu juga ketika seorang pelatih tae kwon do ingin melatih atletnya atau menyampaikan informasi atau pesan kepada atletnya, dia harus memiliki cara atau metode penyampaian yang baik dan menarik, sehingga dengan mudah informasi atau materi yang disampaikan pelatih kepada atletnya dapat diterima dengan baik. 
10 Taupik Rochman ${ }^{1}$

Pengaruh Metode Audiovisual Dengan Metode Demonstrasi Terhadap Penguasaan Teknik Dollyo Chagi

Banyak sekali gerakan-gerakan
dasar yang terdapat dalam olahraga
beladiri tae kwon do diantaranya
dijelaskan oleh Yoyok dalam bukunya
"tae kwon do poomse tae geuk". Ada 5
dasar yaitu : 1) bagian tubuh yang menjadi sasaran/Keop So, 2) Bagian tubuh yang digunakan untuk menyerang atau bertahan, 3) Sikap kuda-kuda/Seogi, 4) Teknik bertahan atau menangkis/Makki 5) Teknik serangan/Kyongkyok Kisul. Yang terdiri dari: a. Pukulan/Jierugi. b. Sabetan/Chigi, c. Tusukan/Chierugi, d. Tendangan/Chagi

Namun demikian, pada saat pertandingan para tae kwon do-in (sebutan bagi atlet tae kwon do) lebih dominan menggunakan teknik kaki dibandingkan dengan teknik tangan. Tendangan yang paling dasar dan memiliki tingkat kesulitan yang tidak terlalu tinggi adalah tendangan dollyo chagi, tendangan ini adalah tendangan serong atau memutar yang membentuk lintasan sabit. Tendangan ini merupakan tendangan yang paling dominan digunakan oleh para tae kwon do-in pada saat bertanding. Karena itulah setiap atlet tae kwon do harus betul-betul menguasai tendangan ini dengan sangat mahir. Seperti yang dijelaskan oleh Munawar (Wasit dan pemegang sabuk DAN IV Jabar) pada wawancara tanggal 21-112004, yang menyatakan bahwa, : "Keunggulan tendangan dollyo chagi merupakan teknik dasar yang sangat mudah untuk dipelajari oleh tae kwon doin dan sangat efektif dan efisien bagi tae kwon do-in untuk meraih angka dalam suatu pertandingan serta memiliki variasi yang lebih banyak dibanding dengan teknik tendangan lain".

Untuk dapat menguasai teknik tendangan dengan baik seorang tae kwon do-in tidak cukup hanya dengan berlatih sekejap saja, tetapi proses latihan harus dilakukan secara teratur dan berkesinambungan, hal ini sesuai dengan pendapat (Sodikun 1991) bahwa : "latihan merupakan suatu kegiatan mengulangulang gerakan yang benar, sampai memperoleh gerakan yang disebut terampil”. Bahkan Harsono (1988:100) juga menambahkan : "latihan teknik adalah latihan untuk mempermahir teknikteknik gerakan yang diperlukan untuk mampu melakukan cabang olahraga yang dilakukan oleh atlet".

Seperti yang telah dijelaskan di atas, untuk memberikan latihan (Winnico, MG Gaos, 2019) atau penyampaian materi atau teknik kepada atlet diperlukan suatu cara atau metode penyampaian yang bagus, sehingga penyampaian yang dilakukan seorang pelatih dapat berlangsung dengan baik dan sukses. Maka penulis tertarik untuk melakukan penelitian tentang cara yang paling bagus dan menarik serta efektif bagi atletnya sehingga setiap pesan atau materi yang ingin disampaikan seorang pelatih dapat tersampaikan dengan baik. Dalam hal ini 
11 Taupik Rochman ${ }^{1}$

Pengaruh Metode Audiovisual Dengan Metode Demonstrasi Terhadap Penguasaan

Teknik Dollyo Chagi

penulis ingin membandingkan antara menyampaikan materi menggunakan metode audiovisual menurut (Taufik, 2019) audiovisual dapat meningkatkan model latihan dan pembelajaran maka penelitian ini dengan metode demonstrasi terhadap peningkatan kemampuan teknik dollyo chagi dalam olahraga beladiri tae kwon do.

Dalam penyampaian materi menggunakan metode audiovisual, setiap testee sebelum melakukan latihan praktek terlebih dahulu menyaksikan tayangan video mengenai bagaimana caranya melakukan teknik dollyo chagi yang benar. Adapun pengertian audiovisual dijelaskan oleh Bahri dan Bahri, et al (2002:141) yaitu media yang mempunyai unsur suara dan unsur gambar. Sedangkan untuk penyampaian materi dengan metode yang kedua yaitu demonstrasi, setiap testee terlebih dahulu menyimak demonstrasi teknik dollyo chagi yang baik dan benar yang dilakukan oleh pelatihnya. Adapun pengertian metode demonstrasi, seperti yang dikemukakan oleh Sagala (2005:210) bahwa metode demonstrasi adalah petunjuk tentang proses terjadinya suatu peristiwa atau benda sampai pada penampilan tingkah laku yang dicontohkan agar dapat diketahui dan dipahami oleh peserta didik secara nyata atau tiruannya. Dengan demikian dapat diketahui apakah terdapat perbedaan dari kedua metode latihan yang digunakan tersebut.

\section{METODE}

Dalam memecahkan suatu masalah diperlukan metode penelitian yang tepat, metode penelitian merupakan suatu cara untuk memecahkan suatu masalah dengan melihat gejala-gejala yang terjadi di masa lampau, masa sekarang maupun masa yang akan datang. Dalam penelitian ini penulis mencari pengaruh variabel tertentu terhadap variabel yang lain, maka metode penelitian yang penulis gunakan adalah metode eksperimen, sebagaimana pendapat yang dikemukakan oleh Riduwan (2005:50) bahwa "penelitian eksperimen adalah suatu penelitian yang berusaha mencari pengaruh variable tertentu terhadap variable yang lain dalam kondisi terkontrol secara ketat".

\section{Populasi dan Sampel}

Populasinya adalah seluruh siswa kelas VII yang mengikuti ekstrakurikuler Taekwondo di Madrasah Tsanawiyah I'anatut Thalibin yang berjenis kelamin laki-laki sebanyak 20 orang, dan pengambilan sampelnya menggunakan teknik total sampling.

\section{Teknik Pengumpulan Data}

Dalam penelitian ini karena belum ada instrumen yang sudah baku untuk mengukur kemampuan teknik dollyo chagi maka instrumen yang digunakan adalah instrumen yang dibuat sendiri berupa butir- butir tes rangkaian gerakan dollyo chagi dari gerakan sebelum menendang sampai gerakan akhir setelah menendang dan setiap gerakan memiliki 


\section{Taupik Rochman ${ }^{1}$}

Pengaruh Metode Audiovisual Dengan Metode Demonstrasi Terhadap Penguasaan Teknik Dollyo Chagi

nilai sempurna yang sudah ditentukan sebelumnya. Instrumen tersebut terdiri dari 3 aspek yaitu 1) sikap permulaan atau sebelum menendang; 2) sikap menendang atau pada saat menendang; dan 3) sikap akhir atau setelah menendang

\section{HASIL dan PEMBAHASAN}

Hasil penghitungan rata-rata dan simpangan baku kelompok A (audiovisual) dan B (demonstrasi) :

\begin{tabular}{|l|l|l|l|}
\hline \multirow{2}{*}{ Kel } & \multicolumn{3}{|l|}{ Tes } \\
\cline { 2 - 4 } & jumlah & rata-rata & $\begin{array}{l}\text { simpangan } \\
\text { baku }\end{array}$ \\
\hline A & 178 & 17.8 & 1.14 \\
\hline B & 159 & 15.9 & 1.38 \\
\hline
\end{tabular}

Hasil pengujian normalitas Lilifors kel A dan B :

\begin{tabular}{|l|l|l|l|l|}
\hline Kel & Tes & Lo tabel & L tabel & kesimpulan \\
\hline \multirow{2}{*}{ A } & Awal & 0 & 0.258 & Normal \\
\cline { 2 - 5 } & Akhir & 0.2286 & 0.258 & Normal \\
\hline \multirow{2}{*}{ B } & Awal & 0 & 0.258 & Normal \\
\cline { 2 - 5 } & Akhir & 0.1454 & 0.258 & Normal \\
\hline
\end{tabular}

Dari penghitungan tersebut maka pendekatan statistika yang digunakan adalah statistika parametrik, karena kedua kelompok sampel berdistribusi normal. Untuk mengetahui tingkat keseragaman sampel yang diambil dari populasi, selanjutnya diuji dengan homogenitas varians dari tiap masing-masing sampel. Pengujian yang dilakukan menggunakan pendekatan statistika uji kesamaan dua variansi.

\begin{tabular}{|l|l|l|l|l|l|}
\hline $\begin{array}{l}\text { Ke } \\
1\end{array}$ & tes & S2 & $\begin{array}{l}\text { Fhitun } \\
\mathrm{g}\end{array}$ & $\begin{array}{l}\text { Ftabe } \\
1\end{array}$ & $\begin{array}{l}\text { Kesimpul } \\
\text { an }\end{array}$ \\
\hline \multirow{2}{*}{ A } & $\begin{array}{l}\text { Awa } \\
1\end{array}$ & 0 & & & \\
\cline { 2 - 5 } & $\begin{array}{l}\text { Akhi } \\
\mathrm{r}\end{array}$ & $\begin{array}{l}1.299 \\
6\end{array}$ & 0 & 3.18 & Homogen \\
\hline \multirow{2}{*}{ B } & $\begin{array}{l}\text { Awa } \\
1\end{array}$ & 0 & & & \\
\hline & $\begin{array}{l}\text { Akhi } \\
\mathrm{r}\end{array}$ & 1.904 & 0 & 3.18 & Homogen \\
\hline
\end{tabular}

Fhitung lebih kecil dari Ftabel, pada $\mathrm{dk}=$ (n-1) atau (9.9) dengan taraf nyata $=0.05$ (0.95) yaitu sebesar 3.18. dapat disimpulkan kedua kelompok mempunyai sampel homogen.

Dilanjutkan dengan uji signifikansi kedua bentuk latihan, sebagai berikut :

\begin{tabular}{|l|l|l|l|}
\hline Kel & Thitung & Ttabel & Kesimpulan \\
\hline A & 49.45 & 2.26 & Signifikan \\
\hline B & 36.14 & 2.26 & Signifikan \\
\hline
\end{tabular}

Hasil penghitungan dan uji signifikansi perbedaan peningkatan hasil latihan kedua kelompok sebagai berikut :

\begin{tabular}{|l|l|l|l|}
\hline kel & thitung & $\begin{array}{l}\text { Ttabel } \\
(0.05: 18\end{array}$ & keterangan \\
\hline A & 3.33 & 1.83 & signifikan \\
\hline B & & \\
\hline
\end{tabular}

Berdasarkan data tersebut thitung 3.33 dan ttabel 1.83 pada tingkat kepercayaan 0.95 dengan penghitungan tabel (1 $\alpha)(n 1-1)$. Pengujian dilakukan dengan pendekatan statistik uji perbedaan dua rata-rata(satu pihak), kriteria pengujian 
13 Taupik Rochman ${ }^{1}$

Pengaruh Metode Audiovisual Dengan Metode Demonstrasi Terhadap Penguasaan Teknik Dollyo Chagi

adalah terima Ho jika $\mathrm{t} \leq \mathrm{t} 1-\alpha$ pada taraf nyata $\alpha=0.05$ dengan $\mathrm{dk}(\mathrm{n} 1+\mathrm{n} 2-2)$ adalah 18. Dalam hal ini thitung berada pada daerah penolakan Ho, jadi Ho ditolak yang artinya terdapat perbedaan dari kedua bentuk latihan.

\section{SIMPULAN}

Berdasarkan hasil pengujian hipotesis dan hasil pengujian yang diperoleh, maka penulis akan menyimpulkan secara keseluruhan dari hasil penelitian yang telah dilakukan. Kesimpulan penelitian pada dasarnya merupakan jawaban permasalahan penelitian yang dikemukakan, maka kesimpulan yang dapat diambil adalah sebagai berikut :

Metode latihan audiovisual memberikan pengaruh yang signifikan terhadap peguasaan teknik dollyo chagi dalam olahraga beladiri tae kwon do.

Metode latihan demonstrasi memberikan pengaruh yang signifikan terhadap penguasaan teknik dollyo chagi dalam olahraga beladiri tae kwon do.

Metode latihan audiovisual memberikan pengaruh yang lebih signifikan dibandingkan dengan metode latihan demonstrasi terhadap penguasaan teknik dollyo chagi dalam olahraga beladiri tae kwon do.

\section{DAFTAR PUSTAKA}

Arikunto, Suharsimi. (2002). Prosedur Penelitian: Suatu Pendekatan Praktek. Jakarta: Rineka Cipta.
Bahri, Syaiful dan Anwan Zain. (2002). Strategi Belajar Mengajar. Jakarta: Rineka Cipta.

Budiwanto, Setyo, (2003) . Jurnal Iptek Olahraga : Prosedur Menyusun Tes Keterampilan Olahraga. Jakarta: Pusat Pengkajian dan Pengembangan IPTEK Olahraga (PPPITOR).

Harsono. (1988). Coaching dan AspekAspek Psikologis dalam Coaching. Jakarta: CV Tambak Kusuma.

Harsono. (2004). Perencanaan Program Latihan. Bandung: FPOK-UPI.

Kurniawan, A. (2018). Hubungan Power Tungkai Dan Power Lengan Terhadap Hasil Spike Dalam Permainan Bola Voli. Maenpo, 8(1), 66.

https://doi.org/10.35194/jm.v8i1.918

Rivan Syukur, M., \& Kastrena, E. (2019). Kontribusi Daya Ledak Otot Lengan Dan Daya Ledak Otot Tungkai Terhadap Hasil Smash. Maenpo, 9(1), 23

https://doi.org/10.35194/jm.v9i1.905 Suherly Dina Saputra, A., \& Syamsul taufik, M. (2019). Korelasi Antara Motor Ability Dengan Keterampilan Dasar Bermain Bola Voli Pada Siswa Berusia 18-19. Maenpo, 9(1), 30.

https://doi.org/10.35194/jm.v9i1.906 Taufik, M. S. (2019). Meningkatkan Teknik Dasar Dribbling Sepakbola 
14 Taupik Rochman ${ }^{1}$

Pengaruh Metode Audiovisual Dengan Metode Demonstrasi Terhadap Penguasaan

Teknik Dollyo Chagi

Melalui Modifikasi Permainan.

Maenpo, 8(1), 26.

Winnico, Mg Gaos, M. T. (2019).

Peningkatan Keterampilan Shooting

Kaki Bagian Dalammelalui Audio-

Visual. Maenpo, 09(1), 1-7.

Kim Un Yong. (1995). Kukkiwon Tae

Kwon Do Text Book. On Sung

Publishins Company.

Ma'mun, Amung. (1996). Teori Belajar

Motorik. Bandung: FPOK IKIP

Bandung.

Nurhasan. (1998). Hand Out Statistik. Bandung: FPOK-UPI.

Nurhasan. (1999). Tes dan Pengukuran

Pendidikan Olahraga. Bandung: FPOK.

Nurhasan. (2000). Pengembangan Sistem

Pembelajaran Modul Mata Kuliah

Tes dan Pengukuran Pendidikan

Olahraga. Bandung: FPOK-UPI.
Riduwan. (2005). Belajar Mudah Penelitian Untuk Guru, Karyawan dan Peneliti Pemula. Bandung: ALFABETA.

Sadiman, Arief. (2005). Media Pendidikan : Pengertian, Pengembangan dan Pemanfaatannya. Jakarta: PT. Raja Grafindo Persada.

Sagala, Syaiful. (2005). Konsep dan Makna Pembelajaran. Bandung: ALFABETA.

Sujana dan Rivai. (1989). Teknologi Pengajaran. Bandung: Sinar Baru.

Sukardi. (2003). Metodologi Penelitian Pendidikan : Kompetensi dan Prakteknya. Jakarta: PT. Bumi Aksara.

Suryadi, Yoyok. (2003). Tae Kwon Do Poomse Tae Geuk. PT. Gramedia Pustaka Utama. 